\title{
Effect of pregnancy on production traits of Canadian Holstein cows
}

\author{
J. Bohmanova, ${ }^{* 1}$ J. Jamrozik, ${ }^{*}$ and F. Migliortł \\ ${ }^{*}$ Centre for Genetic Improvement of Livestock, Department of Animal and Poultry Science, University of Guelph, Guelph, Ontario, \\ Canada, N1G 2W1 \\ †Dairy and Swine Research and Development Centre, Agriculture and Agri-Food Canada, Sherbrooke, Quebec, Canada, J1M 1Z3 \\ $\ddagger$ Canadian Dairy Network, Guelph, Ontario, Canada, N1K 1E5
}

\section{ABSTRACT}

Seven test-day models with different ways of accounting for the effect of pregnancy on production traits were compared by their residual variance, rank correlations of estimated breeding values of bulls and cows and number of nonpregnant cows in the top 500 for milk yield and milk persistency. Data were 22,546,696 first-parity testday milk, fat, and protein yields and somatic cell score records of 2,677,862 Canadian Holstein heifers calved between 1988 and 2006. The first model fitted separate lactation curves to 8 days open classes and 1 curve to a nonpregnant cow class. Two other models adjusted for pregnancy by fitting the effect of month of pregnancy or stage of pregnancy. One model fitted regression on days pregnant. The remaining 3 models fitted interactions between stage of pregnancy and stage of lactation when conception occurred using either regression on days pregnant nested within days open or classes for specific stage of pregnancy and stage of lactation combination. All models were contrasted to a model without any adjustment for the effect of pregnancy. Both models that accounted for the effect of pregnancy and the model without the effect of pregnancy had similar residual variance. Adjusting for the effect of pregnancy did not cause reranking of sires for estimated breeding values for 305-d yield and persistency but influenced ranking of cows. Models that used days open for the effect of pregnancy overestimated breeding values of nonpregnant cows and cows with shorter days open. No interaction was found between stage of pregnancy and stage of lactation. Month of pregnancy and stage of pregnancy models, compared with the model without the effect of pregnancy, decreased overestimation of breeding values of nonpregnant cows and did not overestimate breeding values of cows with short days open like models fitting days open. Month of pregnancy and stage of pregnancy models are recommended for

Received October 6, 2008.

Accepted January 5, 2009.

${ }^{1}$ Corresponding author: jbohmano@uoguelph.ca estimation of adjustment factors for the effect of pregnancy on production traits.

Key words: test-day model, pregnancy status, days open, days pregnant

\section{INTRODUCTION}

Pregnancy has been reported to have a negative effect on milk yield of dairy cows due to hormonal changes, causing regression of the mammary gland (Akers, 2006), and nutrient requirements of the fetus, reducing available nutrients for milk production (Bell et al., 1995). The effect of pregnancy is small at the beginning of gestation and becomes greater at later stages of gestation, when growth and nutrient requirements of the conceptus are larger. Significant effect of pregnancy on milk yield is usually observed from the fifth month of gestation onward (Olori et al., 1997; Haile-Mariam et al., 2003; Roche, 2003). The effect of pregnancy on milk yield depends on lactation stage. The effect is greater in mid lactation than in late lactation (Olori et al., 1997). Haile-Mariam et al. (2003) noted that ignoring the effect of stage of gestation in a test-day model overestimates milk yield at the beginning of the lactation and underestimates it at the end of the lactation.

Cows with greater milk yield during early lactation have longer days open, and longer days open increases the subsequent yield (Lee et al., 1997). Longer days open in the previous lactation positively affect test-day milk and component yields (Bormann et al., 2002). Cows with longer previous days open have greater milk yield in the subsequent lactation because they had more time to renew body fat yield that is used in the next lactation (Sadek and Freeman, 1992). Lee et al. (1997) warned that using days open to adjust for the effect of pregnancy can lead to overcorrection for this effect in a group of cows that conceived early in lactation. This bias is caused by a significant relationship between days open and yield. Brotherstone et al. (2004) reported that cows that conceive shortly after calving had less persistency.

Several countries adjust production traits for pregnancy by including previous, present days open or days 
Table 1. Proportional distribution of test-day records and cows in days open (DO) classes, average length of lactation, milk, fat, and protein yields and SCS of the 9 DO classes

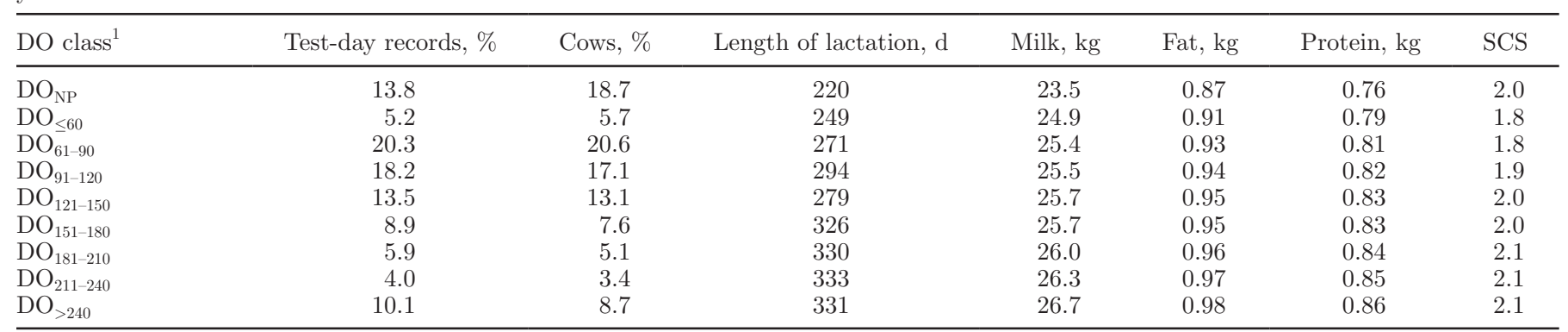

${ }^{1} \mathrm{DO}_{\mathrm{NP}}=$ nonpregnant cows; other classes include DO from $\leq 60$ to $>240 \mathrm{~d}$.

pregnant in their model for genetic evaluation (Interbull, 2008). The current Canadian Test Day Model does not account for the effect of pregnancy and therefore pregnant cows are penalized. The objective of this study was to identify the best model for accounting for the effect in the Canadian Test Day Model for Canadian Holsteins using test-day (TD) records up to 365 DIM.

\section{MATERIALS AND METHODS}

\section{Data}

Data were 22,546,696 TD milk, fat, and protein yield and SCS records of 2,677,862 Canadian Holstein heifers that calved between 1988 and 2006. Only TD with DIM from 5 through $365 \mathrm{~d}$ were included. Averages of milk, fat, and protein yields and SCS were $25.4 \mathrm{~kg}$, $0.93 \mathrm{~kg}, 0.82 \mathrm{~kg}$, and 2.0 , respectively. The pedigree file contained 3,828,921 animals. The insemination data set containing 11,100,925 insemination records was used to determine the cow's conception date of her second pregnancy. Not all cows evaluated in this study had available breeding records because recording of AI began in Canada in 1997.

A gestation length of $280 \mathrm{~d}$ was assumed (the average gestation length of Holsteins). When a cow had a subsequent lactation but no breeding record, the conception date was set to the date $280 \mathrm{~d}$ before her second calving. For a cow with subsequent calving and insemination records located in the interval of $280 \pm$ $15 \mathrm{~d}$ before her second calving, the conception date was set to the date of her last insemination record in this interval. For a cow with incomplete lactation (had a TD record within 6 mo from data set cut-off point) without a second calving but with available insemination records after her first calving, the conception date was set to her last available insemination record. A cow that completed first lactation (did not have any TD record 6 mo from data set cut off point) but did not have a subsequent calving and any insemination records was assumed to be nonpregnant. The last available TD record was assumed to be the first day of the dry period for a cow with lactation in progress. Considering an average dry period of $60 \mathrm{~d}$, the conception date was set to $(280-60)$ days before the last TD record. If such conception date occurred earlier than 125 DIM (average days open of Canadian Holstein cows is 125 d), it was set to $125 \mathrm{~d}$ after the first calving date. Days open (DO) were defined as the days from calving date to conception date. Cows with DO $<14 \mathrm{~d}$ and $>500 \mathrm{~d}$ were excluded from the data.

Cows were grouped into classes based on their DO. The first DO class $\left(\mathbf{D O}_{\mathrm{NP}}\right)$ consisted of nonpregnant cows. Cows with DO $\leq 60 \mathrm{~d}$ were assigned to class $\mathrm{DO}_{1-60}$. Class $\mathrm{DO}_{61-90}$ covered d 61 to 90 , class $\mathrm{DO}_{91-120}$ d 91 to 120 , class $\mathrm{DO}_{121-150}$ d 121 to 150 , class $\mathrm{DO}_{151-180}$ d 151 to 180 , class $\mathrm{DO}_{181-210}$ d 181 to 210 , class $\mathrm{D}_{211-240}$ d 211 to 240. Cows with DO >240 d were assigned to class $\mathrm{DO}_{>240}$. As reported in Table 1, 18.7\% of cows belonged to the $\mathrm{DO}_{\mathrm{NP}}$ class and $51.5 \%$ of cows had days open between 61 and $150 \mathrm{~d}$. The average lactation length ranged between $220 \mathrm{~d}\left(\mathrm{DO}_{\mathrm{NP}}\right)$ and $333 \mathrm{~d}$ $\left(\mathrm{DO}_{211-240}\right)$. The $\mathrm{DO}_{\mathrm{NP}}$ class had the lowest milk, fat, and protein yields. The majority of cows in this group were likely not bred intentionally because of their low production or health problems.

Test-day records were divided into 8 classes of month of pregnancy. Test-date records from cows that conceived but were not pregnant yet on the test-day or TD records from cows that never conceived were assigned into class P0. Classes P1 to P7 included TD records from mo 1 to mo 7 of pregnancy. As reported in Table $2,50.4 \%$ of TD records were recorded before conception and $30.6 \%$ were from the first 4 mo of pregnancy.

Test-day records were divided into 13 stages of pregnancy classes, defined as W1 (days pregnant $\leq 10$ ), W2 $(11 \leq$ days pregnant $\leq 31)$, W3 $(32 \leq$ days pregnant $\leq 52)$, W4 $(53 \leq$ days pregnant $\leq 73)$, W5 $(74 \leq$ days pregnant $\leq 94)$, W6 $(95 \leq$ days pregnant $\leq 115)$, W7 $(116 \leq$ days pregnant $\leq 136)$, W8 $(137 \leq$ days pregnant 
Table 2. Proportional distribution of test-day records in months of pregnancy classes, average DIM, milk, fat, and protein yields, and SCS of the 9 mo of pregnancy classes

\begin{tabular}{lcccccc}
\hline $\begin{array}{l}\text { Month of } \\
\text { pregnancy class }\end{array}$ & Test-day records, \% & DIM, d & Milk, kg & Fat, kg & Protein, kg & SCS \\
\hline P0 & 50.4 & 108 & 27.0 & 0.97 & 0.84 & 1.9 \\
P1 & 7.9 & 145 & 27.1 & 0.97 & 0.87 & 1.8 \\
P2 & 7.9 & 173 & 26.0 & 0.94 & 0.85 & 1.9 \\
P3 & 7.6 & 200 & 25.0 & 0.92 & 0.83 & 1.9 \\
P4 & 7.2 & 226 & 24.0 & 0.90 & 0.80 & 2.0 \\
P5 & 6.8 & 251 & 22.9 & 0.88 & 0.78 & 2.0 \\
P6 & 6.1 & 276 & 21.4 & 0.84 & 0.74 & 2.1 \\
P7 & 6.2 & 301 & 19.1 & 0.78 & 0.67 & 2.2 \\
\hline
\end{tabular}

$\leq 157)$, W9 $(158 \leq$ days pregnant $\leq 178)$, W10 $(179$ $\leq$ days pregnant $\leq 199)$, W11 $(200 \leq$ days pregnant $\leq 220)$, W12 (221 $\leq$ days pregnant $\leq 241)$, and W13 (days pregnant $\geq 242$ ).

\section{Models}

Data were analyzed with 8 multiple-trait random regression models. The effects common to all models (common) were as follows:

$$
\begin{gathered}
\text { common }_{i j k l r}=H T D_{i j}+\sum_{n=0}^{4} \alpha_{i k n} z_{n}(\operatorname{dim})+d i m_{-} c l_{l} \\
+\sum_{n=0}^{4} \beta_{i r n} z_{n}(d i m)+\sum_{n=0}^{4} \gamma_{i r n} z_{n}(d i m),
\end{gathered}
$$

where HTDij was the $j$ th herd-test-date fixed effect for a trait $i$ (TD milk, fat, protein yields, and SCS), $\alpha_{i k n}$ was the $n$th fixed regression coefficient for the $i$ th trait specific to the $k$ th region-age-season class, dim_cl $l_{l}$ was the fixed effect of the $l$ th DIM class $(l=5, \ldots \ldots 365), \beta_{i r n}$ was the $n$th random regression coefficient for the additive genetic effect of animal $r, \gamma_{i r n}$ was the $n$th random regression coefficient for the permanent environmental effect of cow $r, z_{n}(\mathrm{dim})$ was the $n$th Legendre polynomial for DIM. Both fixed and random regressions were fitted with Legendre polynomials of order 4 .

The general $(\mathbf{G})$ model was

$$
y_{i j k l r}=\text { common }_{i j k l r}+e_{i j k l r} \text {, }
$$

where $y_{i j k l r}$ was the TD record for a trait $i$ (TD milk, fat, and protein yields and SCS) and $e_{i j k l r}$ was the residual effect for each observation.

The DO model was

$$
y_{i j k l r s}=\operatorname{common}_{i j k l r}+\sum_{n=0}^{4} \delta_{i s n} z_{n}(d i m)+e_{i j k l r s}
$$

where $\delta_{i s n}$ was the $n$th regression coefficient for the $s$ th DO class, as defined earlier.

The month of pregnancy (MP) model was

$$
y_{i j k l m r}=\operatorname{common}_{i j k l r}+s_{m}+e_{i j k l m r},
$$

where $s_{m}$ is the $m$ th class of month of pregnancy, fitted as a fixed effect with 8 levels.

The days pregnant (DP) model was

$$
y_{i j k l r}=\text { common }_{i j k l r}+\sum_{n=0}^{4} \varepsilon_{i n} w_{n}(d p)+e_{i j k l r},
$$

where $\varepsilon_{i n}$ is the $n$th regression coefficient for trait $i$, and $w_{n}(d p)$ is the $n$th term of the Legendre polynomial of order 4 for $d p$ days pregnant.

The stage of pregnancy $\times$ stage of lactation $(\mathbf{S P} \times$ SL) model was

$$
y_{i j k l r o}=\operatorname{common}_{i j k l r}+\sum_{n=0}^{4} \phi_{i n o} w_{n}(d p)+e_{i j k l r o},
$$

where $\phi_{\text {ino }}=$ the $n$th regression coefficient for the oth stage of lactation. First class of stage of lactation $(o=$ 1) contained records of nonpregnant cows (NP), $o=2$ class consisted of cows with days open shorter than 126 $\mathrm{d}, o=3$ class consisted of cows with days open between 126 and $245 \mathrm{~d}$, and $o=4$ class consisted of cows with days open longer than $245 \mathrm{~d}$.

The days pregnant $\times$ days open $(\mathbf{D P} \times \mathbf{D O})$ model was

$$
y_{i j k l r}=\operatorname{common}_{i j k l r}+\sum_{n=0}^{4} \phi_{i l n} w_{n}(d p)+e_{i j k l r},
$$

where $\phi_{i l n}$ is the $n$th regression coefficient for $l$ th days open class (9 levels). 


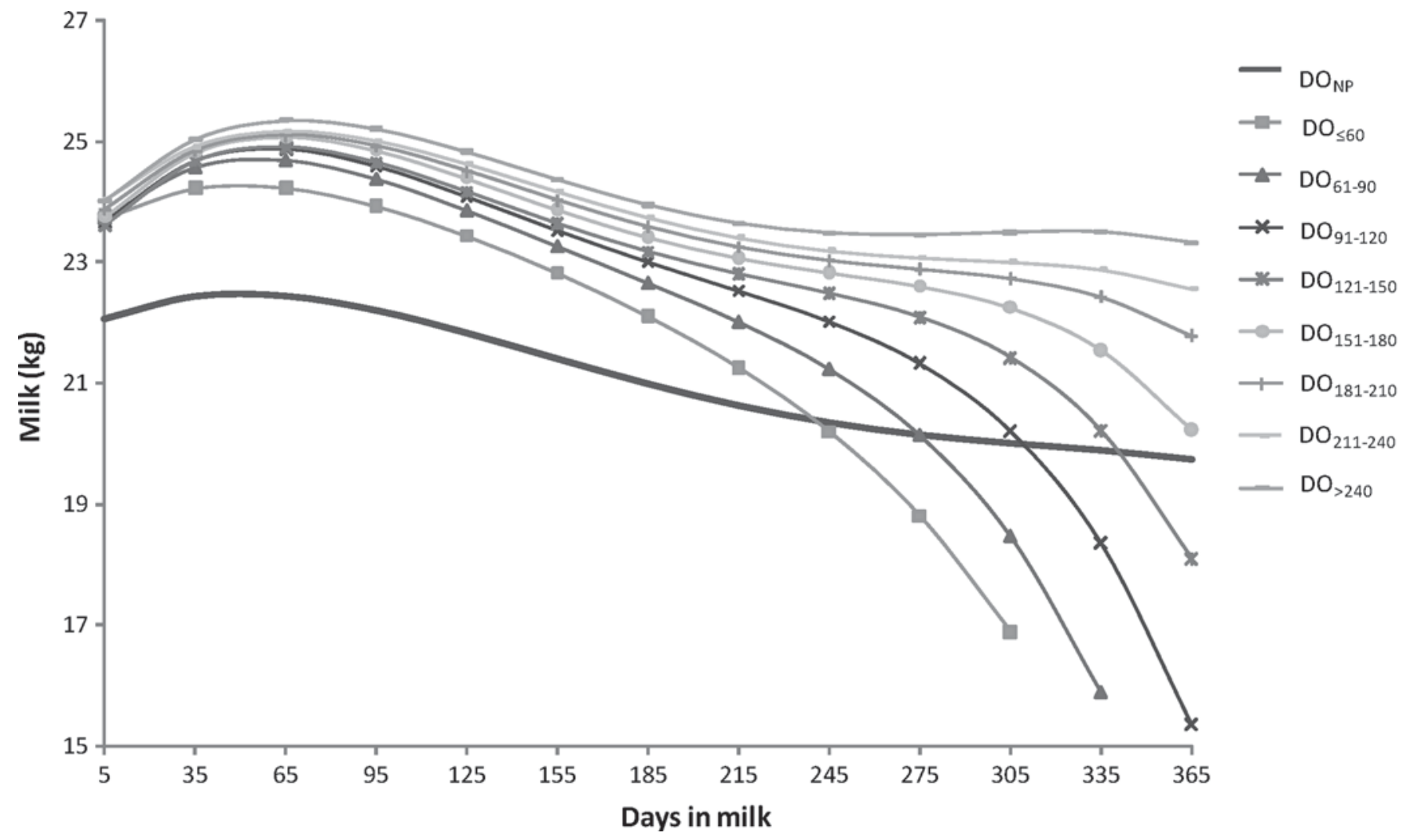

Figure 1. Milk yield curves of nonpregnant cows $\left(\mathrm{DO}_{\mathrm{NP}}\right)$, cows with days open $(\mathrm{DO}) \leq 60 \mathrm{~d}\left(\mathrm{DO}_{<60}\right)$, cows with days open between 61 and $90 \mathrm{~d}\left(\mathrm{DO}_{61-90}\right)$, between 91 and $120 \mathrm{~d}\left(\mathrm{DO}_{91-120}\right)$, between 121 and $150 \mathrm{~d}\left(\mathrm{DO}_{121-150}\right)$, between 151 and $180 \mathrm{~d}\left(\mathrm{DO}_{151-180}\right)$, between 181 and $210 \mathrm{~d}$ $\left(\mathrm{DO}_{181-210}\right)$, between 211 and $240 \mathrm{~d}\left(\mathrm{DO}_{211-240}\right)$, and cows with days open longer than $240 \mathrm{~d}\left(\mathrm{DO}_{>240}\right)$ estimated by days open model.

The month of pregnancy $\times$ days open $(\mathbf{M P} \times \mathbf{D O})$ model was

$$
y_{i j k l u r}=\text { common }_{i j k l r}+t_{p u}+e_{i j k l u r},
$$

where $t_{p u}$ is the effect of $p$ th month of pregnancy class (8 levels) and $u$ th days open class (9 levels).

The stage of pregnancy (SP) model was

$$
y_{i j k l r w}=\operatorname{common}_{i j k l r}+v_{w}+e_{i j k l r w},
$$

where $v_{w}$ is the effect of wth stage of pregnancy class (13 levels), as defined earlier.

In matrix notation each model can be described as

$$
\mathbf{y}=\mathbf{X b}+\mathbf{Z u}+\mathbf{W} \mathbf{p}+\mathbf{e}
$$

where $\mathbf{y}$ was a vector of observations, $\mathbf{b}$ was a vector of HTD, days in milk classes, effect of pregnancy, and regression coefficients for region-age-season class and $\mathbf{u}, \mathbf{p}$, and $\mathbf{e}$ were vectors of additive genetic, permanent environmental, and residual values, respectively; $\mathbf{X}, \mathbf{Z}$, and $\mathbf{W}$ were incidence matrices. Data were assumed to follow

$$
\mathbf{y} \mid \mathbf{b}, \mathbf{u}, \mathbf{p}, \mathbf{R} \sim M V N(\mathbf{X b}+\mathbf{Z u}+\mathbf{W} \mathbf{p}, \mathbf{R}),
$$

and

$$
\operatorname{var}\left[\begin{array}{l}
\mathbf{u} \\
\mathbf{p} \\
\mathbf{e}
\end{array}\right]=\left(\begin{array}{ccc}
\mathbf{G} \otimes \mathbf{A} & 0 & 0 \\
0 & \mathbf{P} \otimes \mathbf{I} & 0 \\
0 & 0 & \mathbf{R}
\end{array}\right),
$$

where $\mathbf{R}$ was a $4 \times 4$ covariance matrix for the residual. Residual variance was assumed to be constant across lactation. Matrices $\mathbf{G}$ and $\mathbf{P}$ were the random regression covariance matrices for the genetic and permanent environmental effects, respectively. The size of both matrices was $(5 \times 4)$ by $(5 \times 4)$, where 5 is the size of the vector of random regression coefficients and 4 is the number of traits. The matrix $\mathbf{A}$ was the additive genetic relationship matrix and $\mathbf{I}$ was an identity matrix. All models used the same (co)variance components estimated previously by Bohmanova et al. (2008). Mixed 


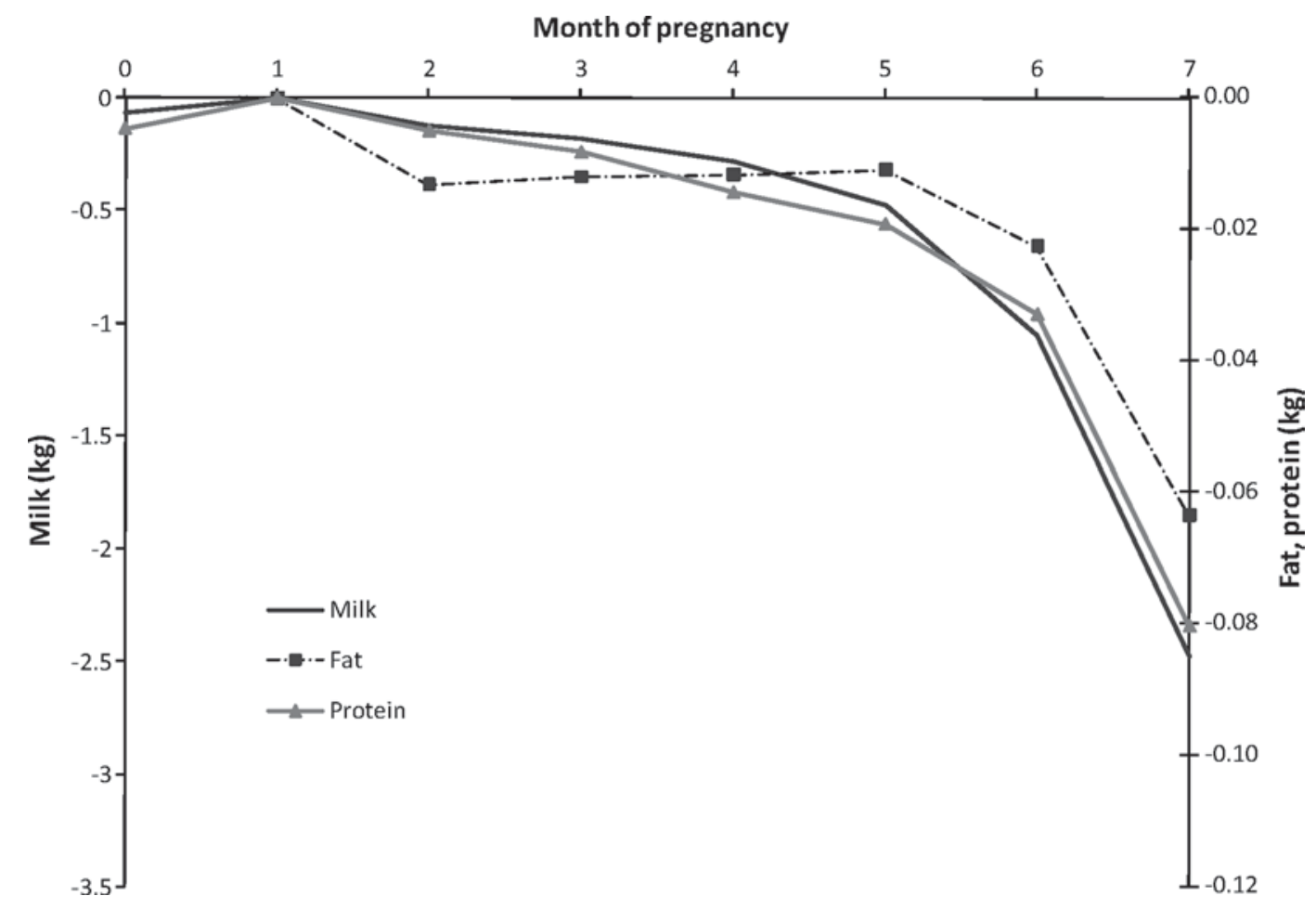

Figure 2. Effects of month of pregnancy on milk, fat and protein yields estimated by month of pregnancy (MP) model.

model equations were solved with BLUPF90IOD (Tsuruta et al., 2001), software that uses the preconditioned conjugate gradient algorithm with iteration on data.

\section{Model Comparison}

To predict changes in rankings of bulls and cows after implementation of one of the models, Spearman rank correlations of 305-d EBV of bulls with $\geq 25$ daughters estimated from model $\mathrm{G}$ (no adjustment) and other models, rank correlations of 305-d EBV of cows and rank correlations of EBV for persistency were calculated. Lactation persistency EBV (PER) were calculated as difference of 280-d and 60-d EBV:

$$
P E R_{i r}=\sum_{n=0}^{4} \beta_{i r n} z_{n}(280)-\sum_{n=0}^{4} \beta_{i r n} z_{n}(60)
$$

where $\beta_{i r n}$ was the $n$th estimate of the random regression coefficient for the additive genetic effect of animal $r$ and trait $i$, and $z_{n}(280)$ and $z_{n}(60)$ are values of the $n$th Legendre polynomial for 280 and 60 DIM, respectively.

Possible overestimation of EBV of nonpregnant cows related to choice of the model was investigated by comparing the numbers of nonpregnant and pregnant cows in the top 500 list for milk yield and persistency. If model G overestimates EBV of nonpregnant cows, then a model that correctly accounts for pregnancy should have smaller number of nonpregnant cows in the top 500 list than model G. Models were further compared by residual variance $(\mathbf{R V})$ defined as

$$
R V=\frac{\sum_{i=1}^{m}\left(y_{i}-\hat{y}_{i}\right)^{2}-\frac{\left[\sum_{i=1}^{m}\left(y_{i}-\hat{y}_{i}\right)\right]^{2}}{m}}{m-1},
$$

where $y_{i}$ is the $i$ th observed test-day record, $\hat{y}_{i}$ is the $i$ th predicted test-day record, and $m$ is the number of records.

\section{RESULTS AND DISCUSSION}

Model DO fitted separate curves for nonpregnant and each of the 8 DO classes. As reported in Figure 1 , curves of cows with larger DO were above curves of cows with shorter DO. Because the differences in level of production among classes occurred from the very beginning where none of the cows were pregnant, it clearly indicates that this model also accounted for factors not related to the effect of pregnancy. This artifact of this model was likely caused by a high positive correlation (0.62) between DO and milk yield (Abdallah 


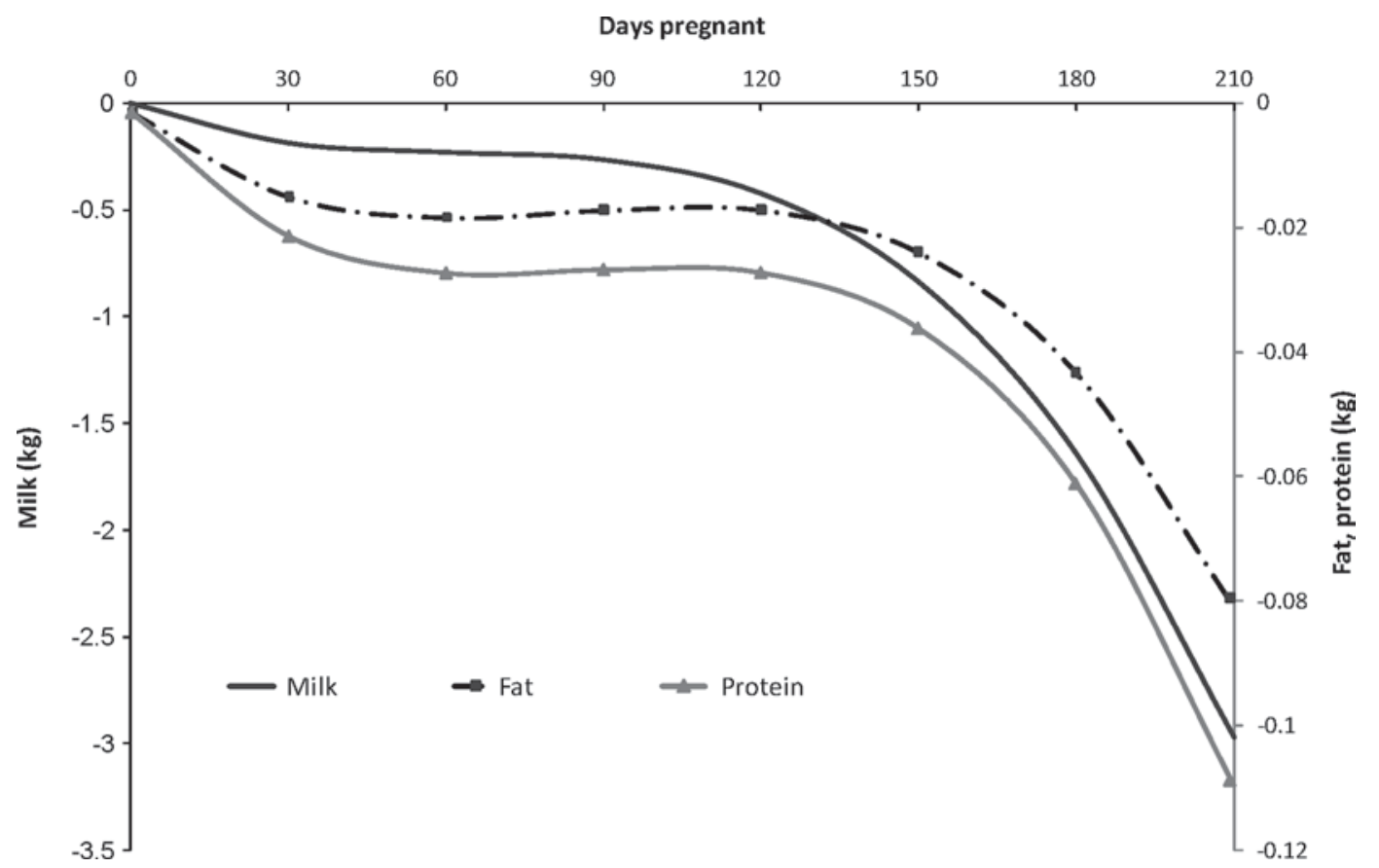

Figure 3. Decline of milk, fat and protein yields estimated by days pregnant (DP) model.

and McDaniel, 2000). High-yielding cows tend to conceive later in lactation (i.e., have longer DO) compared with cows with average or low production (Makuza and McDaniel, 1996), probably because of biological antagonism between energy balance and reproductive cycling (Lee et al., 1997). Curves of cows with shorter DO had less persistency than cows with more DO, which is consistent with results by Brotherstone et al. (2004). As reported in Table 1, the average milk yield of the nonpregnant group was less than the average milk yield of pregnant cows. Cows in the nonpregnant class were mainly animals with low production that were not kept for subsequent lactation or animals with health problems yielding less milk and having difficulty becoming pregnant. The average curve of the nonpregnant group estimated by model DO was consequently lower than the curves of pregnant cows; this difference was not due to the effect of pregnancy but because the cows with low production were not bred. This model overestimated breeding values of nonpregnant cows, because their test-day yield was contrasted to an average curve that was below the curve of pregnant cows. Also, breeding values of cows with shorter DO were inflated because their average curve was below the curve of cows with longer DO. The shape of curves was reasonably consistent up to 185 DIM, as cows in the DO $\leq 60$ class start their fourth month of pregnancy when the effect of pregnancy became apparent. Larger fluctuation of EBV of cows can be expected with the DO model from one genetic evaluation to the next. A proportion of cows with lactation in progress that in a previous genetic evaluation belonged to the nonpregnant class will change their status from nonpregnant to pregnant in the next genetic evaluation. Test-day yield of such cows will be compared in the first genetic evaluation to an average curve of nonpregnant cows and in the second evaluation to an average curve of pregnant cows, which is higher than the curve of nonpregnant cows. Consequently, EBV of these cows will likely decrease.

Model MP accounted for pregnancy by estimating the effect of gestation separately for each month of pregnancy. In Canada, the common practice is to dryoff cows 2 mo before calving. Therefore, the effect of pregnancy was limited to only 7 mo. As presented in Figure 2, milk and protein yields declined slowly in the first $4 \mathrm{mo}$ and then the slope of the decline increased. The rate of decline of fat yield was $0.02 \mathrm{~kg}$ greater in the second compared with the first month of pregnancy and then remained constant until the fifth month, when the rate of decline was 2 to 6 times larger.

Model DP used a regression to estimate the effect of pregnancy on production (Figure 3). Similar to model MP, milk yield declined slowly during the first 4 mo of pregnancy and then more quickly, which is in agreement with results from Druet et al. (2003), Leclerc et al. (2008), and Olori et al. (1997). In contrast to model MP, a larger decrease was observed between the first and second months of pregnancy. Moreover, the rate 


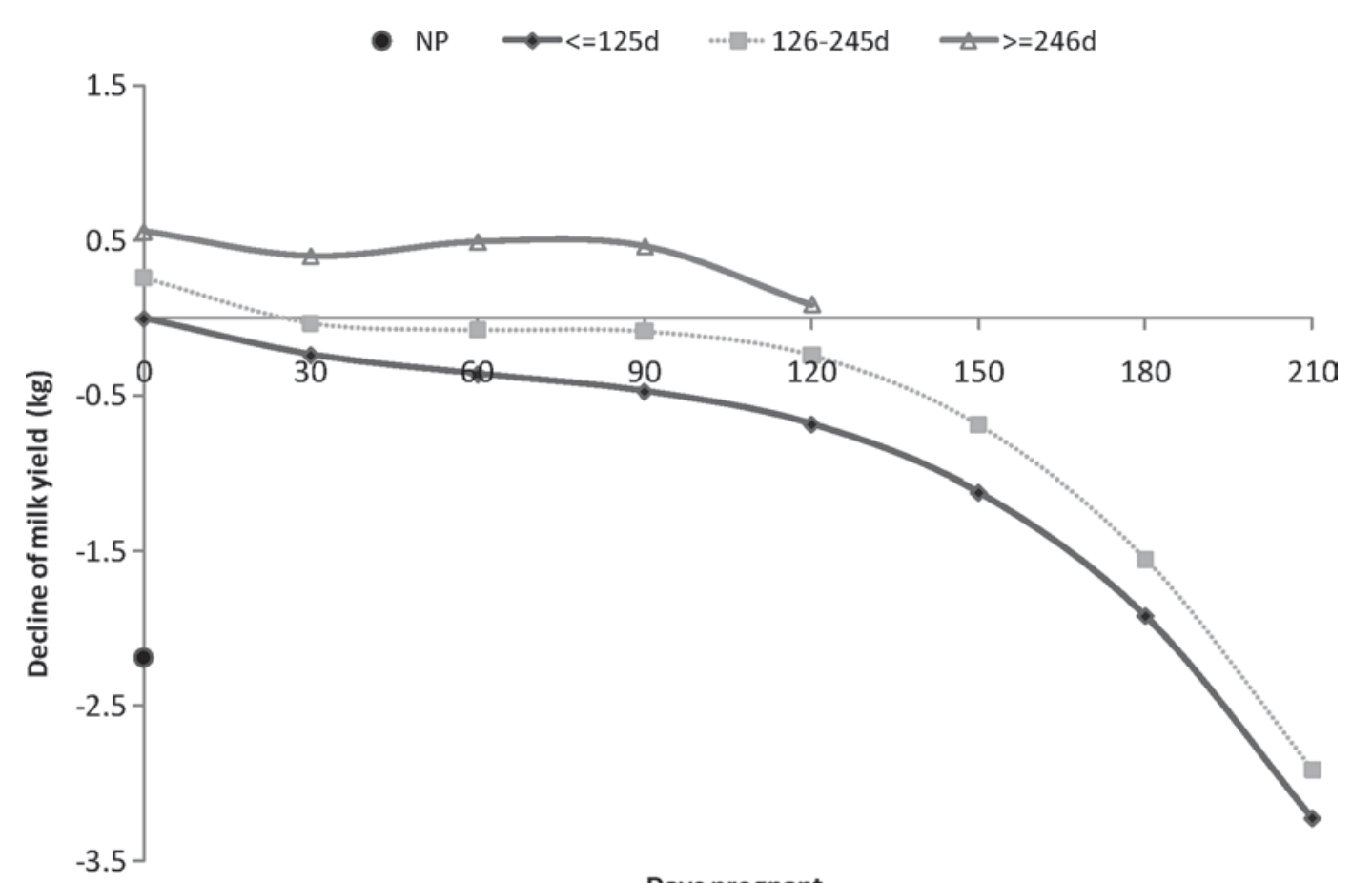

Days pregnant

Figure 4. Decline of milk due to pregnancy estimated by stage of pregnancy $\times$ stage of lactation model $(\mathrm{SP} \times \mathrm{SL})$ for nonpregnant cows $(\mathrm{NP})$, cows with days open shorter than $126 \mathrm{~d}(\leq 125 \mathrm{~d})$, days open between 126 and $245 \mathrm{~d}(126-245 \mathrm{~d})$ and with days open longer than $245 \mathrm{~d}$ $(\geq 246 \mathrm{~d})$.

of decline in the second phase of pregnancy was larger in model DP than in model MP. This was most likely caused by the fact that Legendre polynomials tend to overestimate curve at its edges.

Models $\mathrm{SP} \times \mathrm{SL}, \mathrm{DP} \times \mathrm{DO}$, and $\mathrm{MP} \times \mathrm{DO}$ assumed that the rate of decline in production traits due to pregnancy was influenced by the stage of lactation when the cow conceived. However, as reported in Figures 4, 5, and 6 , the curves were relatively uniform in their shape, indicating that the effect of pregnancy did not depend on the stage of lactation. Sharma et al. (1990) and Olori et al. (1997) reported a significant interaction between stage of pregnancy and number of weeks open. In general, cows with shorter days open have less-persistent lactations than cows with longer days open (Schneider et al., 1981), and because none of the studies accounted for individual shape of lactation curve, their results are probably slightly biased. As in model DO, the curves estimated for cows with shorter DO were below curves estimated for cows with longer DO.

Figure 7 illustrates the decline in milk, fat, and protein yields of the 13 stages of pregnancy for model SP. Likewise, in the MP model, milk and protein yield declined slowly from conception until the fourth month of pregnancy. The rate of decline was noticeably greater at later stages of pregnancy. In contrast to that of milk and protein yields, the rate of decline of fat yield was relatively high in the first $2 \mathrm{mo}$ and then leveled off and became evident from the fifth month of pregnancy.

Spearman rank correlations between 305-d EBV of 9,214 bulls with $\geq 25$ daughters estimated by model $G$ and remaining models were all $\geq 0.991$, indicating that adjustment for the effect of pregnancy will have little effect on EBV of proven bulls. Spearman correlations of $2,752,424$ cows were smaller than correlations for bulls (Table 3). Spearman correlations for cows from models $\mathrm{MP}, \mathrm{DP}$, and SP were $\geq 0.99$ but these correlations for models $\mathrm{DO}, \mathrm{SP} \times \mathrm{SL}, \mathrm{DP} \times \mathrm{DO}$, and $\mathrm{MP} \times \mathrm{DO}$ were $<0.99$.

Spearman correlations of EBV for persistency of 2,752,424 cows between model $\mathrm{G}$ and the remaining models are reported in Table 4 . The correlations for production traits ranged between 0.968 (milk yield in $\mathrm{SP}$ model) and 0.991 (fat yield in DP and MP $\times$ DO), suggesting that pregnancy has an effect on persistency of production traits.

Table 5 reports the percentage of nonpregnant and pregnant cows in the top 500 for milk yield EBV. Models that accounted for the effect of pregnancy using days open $(\mathrm{DO}, \mathrm{SP} \times \mathrm{SL}, \mathrm{DP} \times \mathrm{DO}, \mathrm{MP} \times \mathrm{DO})$ had larger percentages of nonpregnant cows in the top 500 than model $\mathrm{G}$, indicating that overestimation of breeding values of nonpregnant cows is greater with these 4 models than with model G. Models MP and SP had 


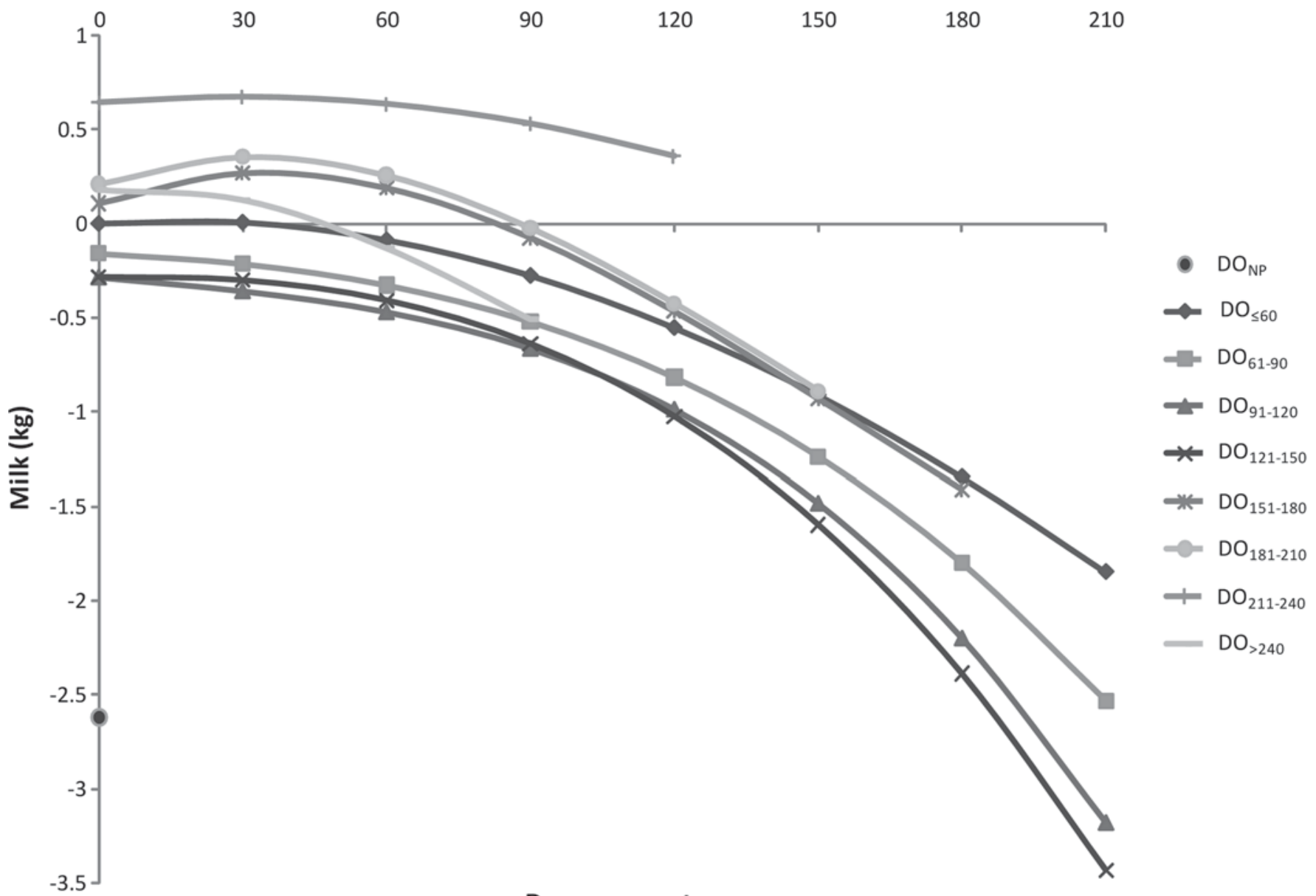

Days pregnant

Figure 5. Decline of milk curves of nonpregnant cows $\left(\mathrm{DO}_{\mathrm{NP}}\right)$, cows with days open (DO) $\leq 60 \mathrm{~d}(\mathrm{DO}<60$ ), cows with days open between 61 and $90 \mathrm{~d}\left(\mathrm{DO}_{61-90}\right)$, between 91 and $120 \mathrm{~d}\left(\mathrm{DO}_{91-120}\right)$, between 121 and $150 \mathrm{~d}\left(\mathrm{DO}_{121-150}\right)$, between 151 and $180 \mathrm{~d}\left(\mathrm{DO}_{151-180}\right)$, between 181 and $210 \mathrm{~d}\left(\mathrm{DO}_{181-210}\right)$, between 211 and $240 \mathrm{~d}\left(\mathrm{DO}_{211-240}\right)$, and cows with days open longer than $240 \mathrm{~d}\left(\mathrm{DO}_{>240}\right)$ estimated by days pregnant $\times$ days open $(\mathrm{DP} \times \mathrm{DO})$ model.

$10 \%$ fewer nonpregnant cows in the top 500 for milk than model $\mathrm{G}$, indicating that these models decrease overestimation of EBV of nonpregnant cows compared with model G.

Table 6 compares distribution of cows by DO class in the top 500 for milk. Models DO, SP $\times$ SL, DP $\times \mathrm{DO}$, and $\mathrm{MP} \times \mathrm{DO}$ had, in the top 500 for milk, smaller numbers of cows with DO $>240 \mathrm{~d}$ than model $\mathrm{G}$, indicating that these models underestimate EBV of cows with long DO, as previously mentioned. No apparent differences in the number of cows in the DO classes were found between MP and SP models and model G.

Distribution of cows by DO class in the top 500 for persistency of milk yield is reported in Table 7. All models with an effect of pregnancy had a smaller number of nonpregnant cows in the top 500 for persistency than did model G. This indicates that adjustment for the effect of pregnancy increases EBV for persistency of pregnant cows. All models with an effect of pregnancy had larger numbers of cows in $\mathrm{DO} \leq 60$, DO $\leq 90, \mathrm{DO} \leq 120$, and $\mathrm{DO} \leq 150$ classes and smaller numbers in remaining DO classes compared with model G. This is mainly because a test-day yield on 280 DIM and consequently EBV on $280 \mathrm{~d}$ (EBV that was used for calculation of EBV for persistency) was noticeably affected by pregnancy only in a group of cows that conceived before 150 DIM (considering that effect of pregnancy does not have a considerable effect until 130 d pregnant). Consequently, implementation of any of the models with the effect of pregnancy would increase persistency EBV of cows with shorter DO and decrease EBV of nonpregnant cows and cows with longer DO.

Figure 8 reports a trend of RV by DIM for milk yield. The RV of all models was identical in mid lactation. As in Haile-Mariam et al. (2003), ignoring of the effect of pregnancy (model G) caused an increase of RV at the 


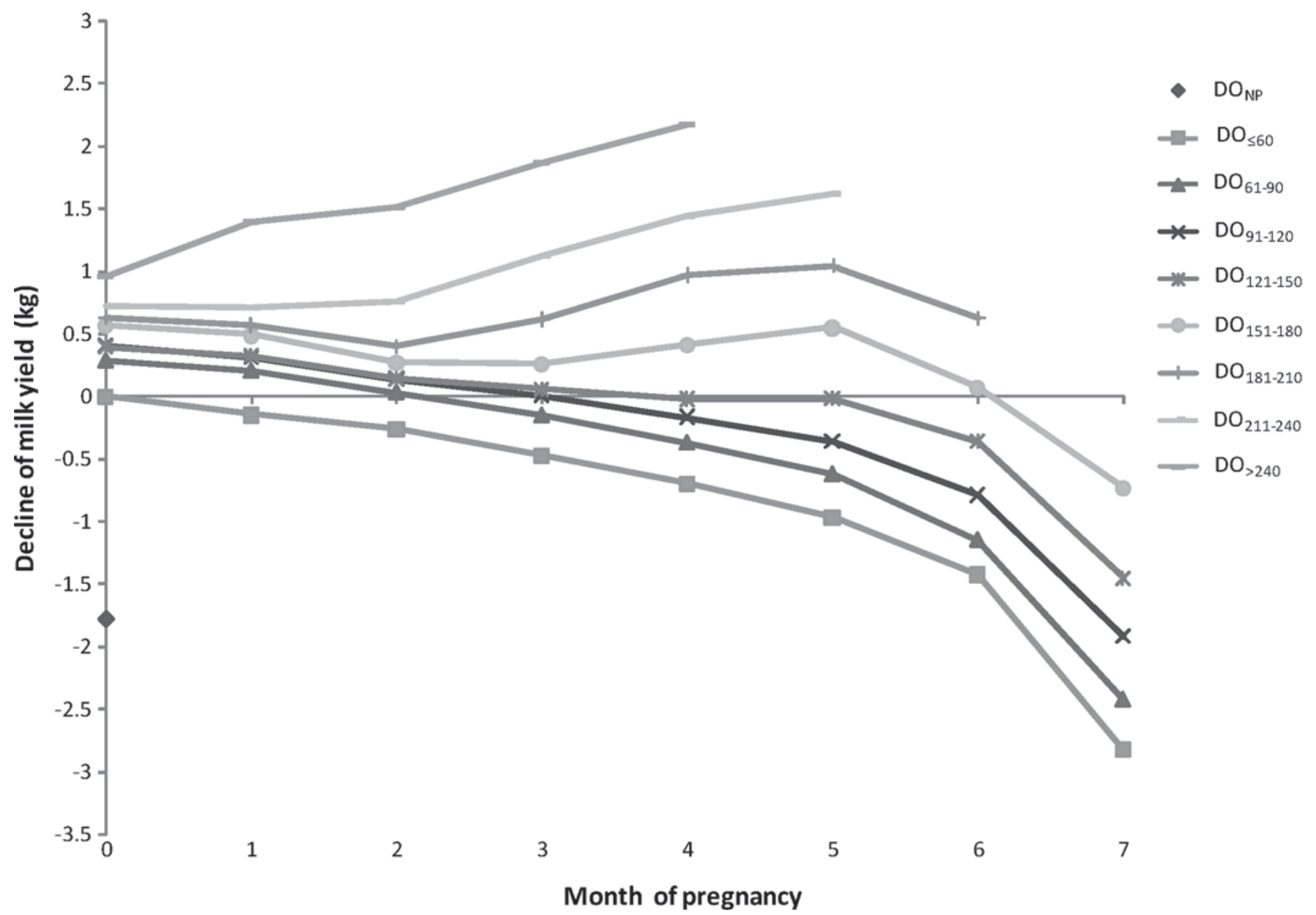

Figure 6. Decline of milk yield curves of nonpregnant cows $\left(\mathrm{DO}_{\mathrm{NP}}\right)$, cows with days open $(\mathrm{DO}) \leq 60 \mathrm{~d}(\mathrm{DO} \leq 60)$, cows with days open between 61 and $90 \mathrm{~d}\left(\mathrm{DO}_{61-90}\right)$, between 91 and $120 \mathrm{~d}\left(\mathrm{DO}_{91-120}\right)$, between 121 and $150 \mathrm{~d}\left(\mathrm{DO}_{121-150}\right)$, between 151 and $180 \mathrm{~d}\left(\mathrm{DO}_{151-180}\right)$, between 181 and $210 \mathrm{~d}\left(\mathrm{DO}_{181-210}\right)$, between 211 and $240 \mathrm{~d}\left(\mathrm{DO}_{211-240}\right)$, and cows with days open longer than $240 \mathrm{~d}\left(\mathrm{DO}_{>240}\right)$ estimated by month of pregnancy $\times$ days open $(\mathrm{MP} \times \mathrm{DO})$ model.

beginning and end of lactation (between 276 and 365 DIM). Small differences in RV were reported among models. Model MP had the largest RV and models SP $\times \mathrm{SL}$ and $\mathrm{DP} \times \mathrm{DO}$ had the smallest RV. In general, models that considered DO in their definition of effect of pregnancy had smaller RV. As mentioned before, the models with DO incorrectly removed a part of variability that was not related to pregnancy and therefore RV was not an appropriate criterion for model comparison in this case.

Two approaches can be employed to incorporate the effect of pregnancy in the national genetic evaluation.

Table 3. Correlation between EBV of sires with more than 25 daughters ( $\mathrm{n}=9,214$ sires) predicted by model $\mathrm{G}$ (the general model) and other models

\begin{tabular}{lccccccc}
\hline & \multicolumn{7}{c}{ Model $^{1}$} \\
\cline { 2 - 7 } Trait & DO & MP & DP & SP $\times$ SL & DP $\times$ DO & MP $\times$ DO & SP \\
\hline Milk & 0.994 & 0.994 & 0.999 & 0.992 & 0.992 & 0.996 & 0.994 \\
Fat & 0.994 & 0.994 & 0.999 & 0.992 & 0.991 & 0.996 & 0.994 \\
Protein & 0.995 & 0.994 & 0.998 & 0.993 & 0.993 & 0.997 & 0.994 \\
SCS & 0.999 & 0.999 & 1.000 & 1.000 & 1.000 & 1.000 & 0.999 \\
\hline
\end{tabular}

${ }^{1} \mathrm{DO}=$ days open model; $\mathrm{MP}=$ month of pregnancy model; $\mathrm{DP}=$ days pregnant model; $\mathrm{SP} \times \mathrm{SL}=$ stage of pregnancy $\times$ stage of lactation model; $\mathrm{DP} \times \mathrm{DO}=$ days pregnant $\times$ days open model; $\mathrm{MP} \times \mathrm{DO}=$ month of pregnancy $\times$ days open; $\mathrm{SP}=$ stage of pregnancy model. 


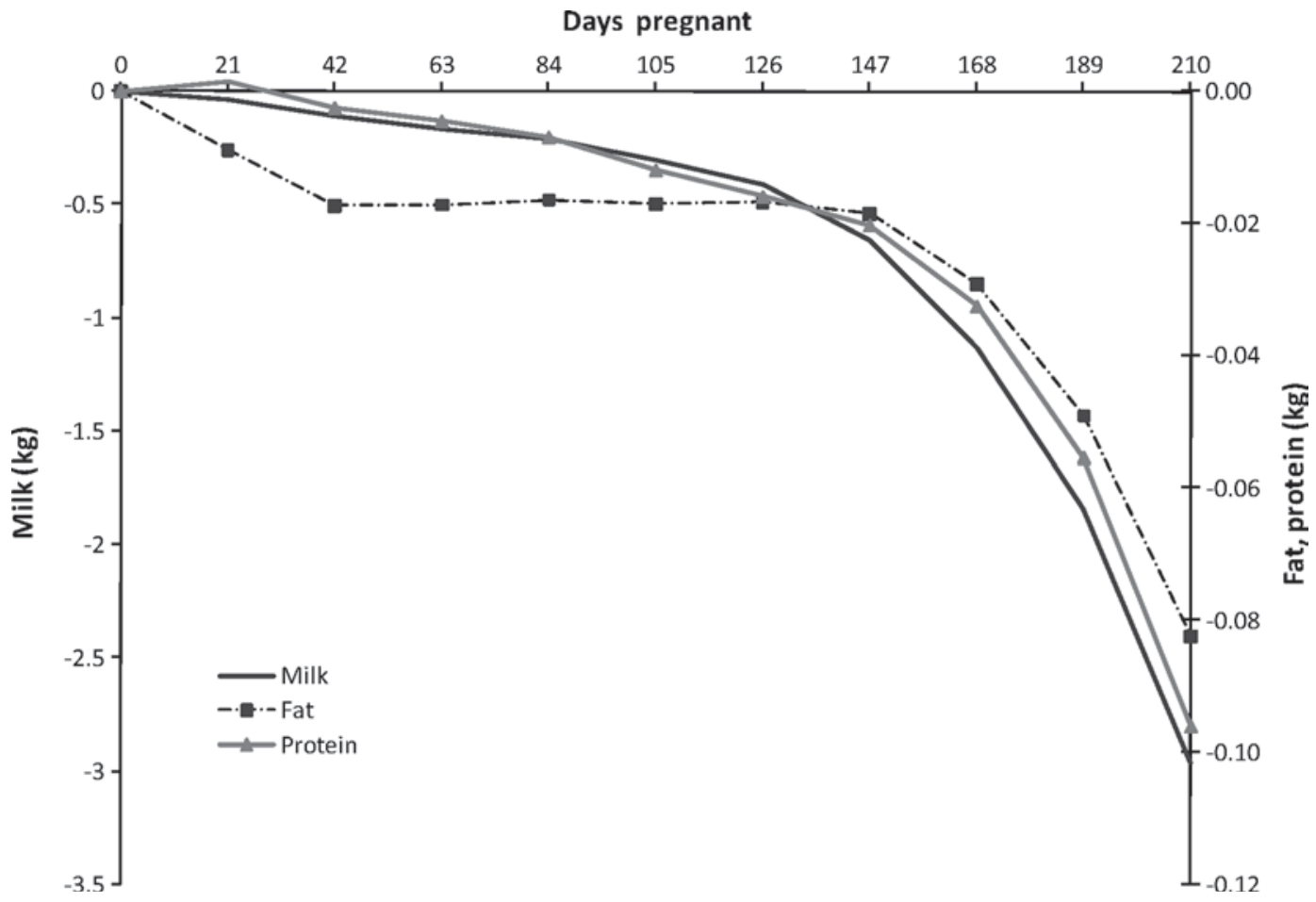

Figure 7. Decline of milk, fat, and protein yields due to pregnancy estimated by stage of pregnancy (SP) model.

The first option is to expand the genetic evaluation model to include an additional effect. The second option is to preadjust data using previously estimated adjustment factors and leave the genetic evaluation model unchanged. The advantages of the second approach are that it can significantly decrease computational cost (Leclerc et al., 2008) and the adjustment factors can be calculated from a subset of data with validated conception dates. These factors will be more accurate than estimates from a complete data set, in which conception date would be approximated for some animals. Moreover, the adjustment factors can be smoothed out to remove any changes that do not have a biological explanation. However, the drawback of this approach is the lack of accounting for the error term in the estimates of correction factors may cause biases in covariance components and prediction of breeding values (Varona et al., 1999).

The effect of pregnancy on milk yield is stronger in multiparous than primiparous cows as early as the 25th week of pregnancy (Coulon et al., 1995; Brotherstone et al., 2004; Leclerc et al., 2008). Therefore, implementation of preadjustment of pregnancy into a routine national genetic evaluation would require separate adjustment factors for primiparous and multiparous cows.

\section{CONCLUSIONS}

Residual variance and ranking of sires for 305-d EBV and persistency EBV was not different among models.

Table 4. Correlation between EBV for persistency of cows with at least 1 test-day record $(\mathrm{n}=2,752,424$ cows) predicted by model $\mathrm{G}$ (the general model) and other models

\begin{tabular}{lccccccc}
\hline & \multicolumn{7}{c}{ Model $^{1}$} \\
\cline { 2 - 7 } Trait & DO & MP & DP & SP $\times$ SL & DP $\times$ DO & MP $\times$ DO & SP \\
\hline Milk & 0.972 & 0.981 & 0.978 & 0.970 & 0.971 & 0.977 & 0.968 \\
Fat & 0.989 & 0.989 & 0.991 & 0.987 & 0.987 & 0.991 & 0.984 \\
Protein & 0.972 & 0.984 & 0.981 & 0.974 & 0.973 & 0.978 & 0.974 \\
SCS & 0.997 & 0.990 & 0.997 & 0.993 & 0.993 & 0.998 & 0.995 \\
\hline
\end{tabular}

${ }^{1} \mathrm{DO}=$ days open model; $\mathrm{MP}=$ month of pregnancy model; $\mathrm{DP}=$ days pregnant model; $\mathrm{SP} \times \mathrm{SL}=$ stage of pregnancy $\times$ stage of lactation model; DP $\times$ DO $=$ days pregnant $\times$ days open model; $\mathrm{MP} \times \mathrm{DO}=$ month of pregnancy $\times$ days open; $\mathrm{SP}=$ stage of pregnancy model. 
Table 5. Number (\% in parentheses) of nonpregnant and pregnant cows in the top 500 for milk yield EBV

\begin{tabular}{|c|c|c|c|c|c|c|c|c|}
\hline Group & \multicolumn{8}{|c|}{ Model $^{1}$} \\
\hline Nonpregnant & $53(11)$ & $86(17)$ & $48(10)$ & $56(11)$ & $101(20)$ & $102(20)$ & $80(16)$ & $48(10)$ \\
\hline
\end{tabular}

${ }^{1} \mathrm{G}=$ general model; $\mathrm{DO}=$ days open model; $\mathrm{MP}=$ month of pregnancy model; $\mathrm{DP}=$ days pregnant model; $\mathrm{SP} \times \mathrm{SL}=$ stage of pregnancy $\times$ stage of lactation model; $\mathrm{DP} \times \mathrm{DO}=$ days pregnant $\times$ days open model; $\mathrm{MP} \times \mathrm{DO}=$ month of pregnancy $\times$ days open; SP $=$ stage of pregnancy model.

However, choice of model had an effect on ranking of 305-d EBV and EBV for persistency for cows. Models fitting DO overestimated breeding values of nonpregnant cows and cows that conceived early in lactation. Stage of lactation at conception did not have a noticeable effect on the size of the effect of pregnancy, indicating an absence of interaction between stage of pregnancy and stage of lactation. Month of pregnancy and stage of pregnancy models were the only 2 models that decreased overestimation of breeding values of nonpregnant cows and did not overestimate breeding values of cows with short days open. Month of pregnancy and stage of pregnancy models are recommended for estimation of preadjustment factors of the effect of pregnancy for a routine genetic evaluation of production traits in Canada.

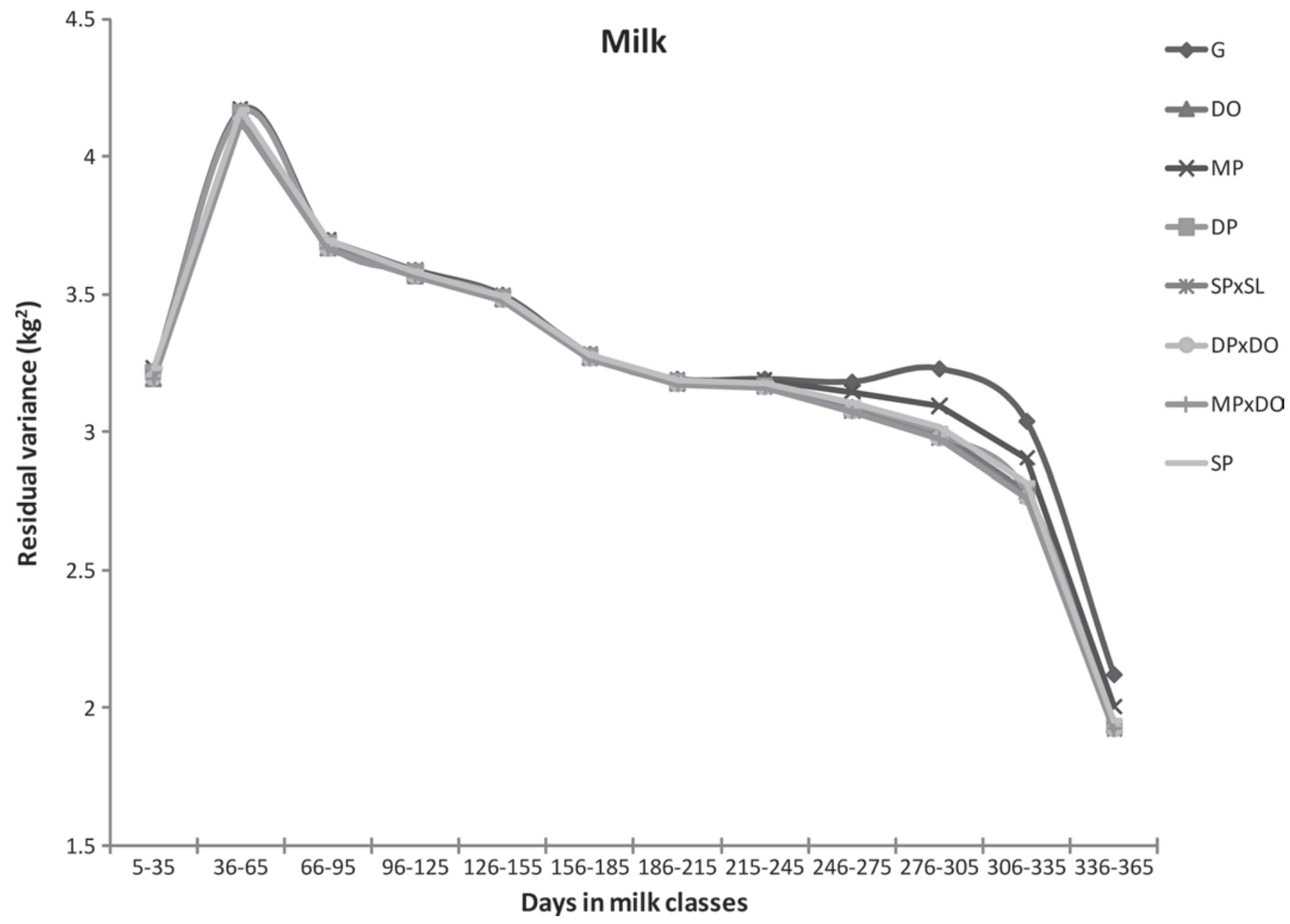

Figure 8. Trend of residual variance across lactation for milk yield estimated by different models: $\mathrm{G}=$ general model; $\mathrm{DO}=\mathrm{days}$ open model; $\mathrm{MP}=$ month of pregnancy model; $\mathrm{DP}=$ days pregnant model; $\mathrm{SP} \times \mathrm{SL}=$ stage of pregnancy $\times$ stage of lactation model; $\mathrm{DP} \times \mathrm{DO}=$ days pregnant $\times$ days open model; MP $\times \mathrm{DO}=$ month of pregnancy $\times$ days open; SP $=$ stage of pregnancy model. 
Table 6. Number of cows in the 9 days open (DO) classes in the top 500 for milk yield EBV

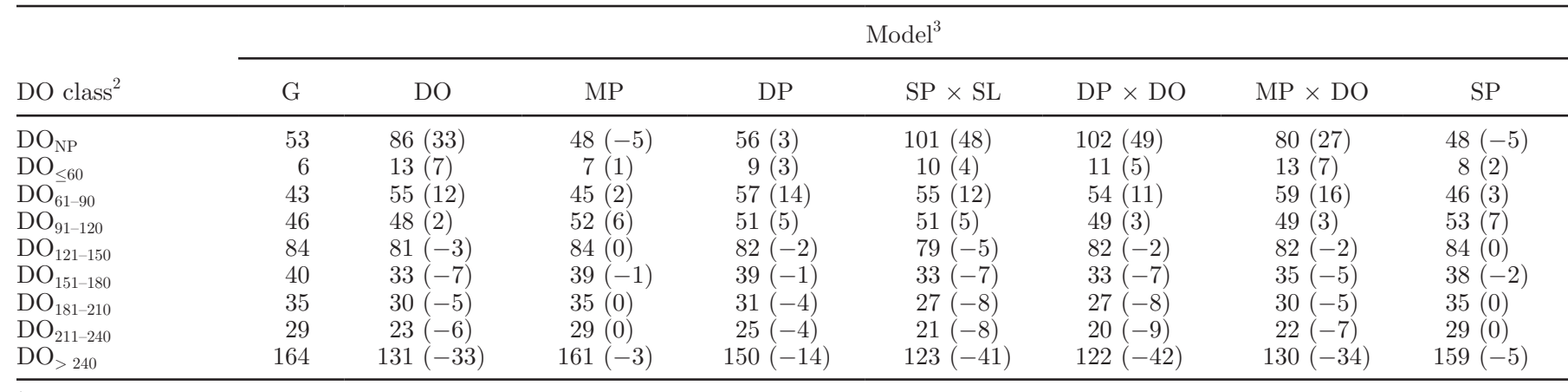

${ }^{1}$ Change in number of cows compared with model $\mathrm{G}$ is in parentheses.

${ }^{2} \mathrm{DO}_{\mathrm{NP}}=$ nonpregnant cows; other classes include $\mathrm{DO}$ from $\leq 60$ to $>240 \mathrm{~d}$.

${ }^{3} \mathrm{G}=$ general model; $\mathrm{DO}=$ days open model; $\mathrm{MP}=$ month of pregnancy model; $\mathrm{DP}=$ days pregnant model; SP $\times \mathrm{SL}=$ stage of pregnancy $\times$ stage of lactation model; $\mathrm{DP} \times \mathrm{DO}=$ days pregnant $\times$ days open model; $\mathrm{MP} \times \mathrm{DO}=$ month of pregnancy $\times$ days open; SP $=$ stage of pregnancy model.

Table 7. Number of cows in the 9 days open (DO) classes in the top 500 for persistency of milk yield EBV ${ }^{1}$

\begin{tabular}{|c|c|c|c|c|c|c|c|c|}
\hline DO class $^{2}$ & \multicolumn{8}{|c|}{ Model $^{3}$} \\
\hline $\mathrm{DO}_{61-90}^{-}$ & 34 & $77(43)$ & $59(25)$ & $70(36)$ & $65(31)$ & $64(30)$ & $67(33)$ & $77(43)$ \\
\hline $\mathrm{DO}_{91-120}$ & 38 & $61(23)$ & $47(9)$ & $66(28)$ & $53(15)$ & $52(14)$ & $53(15)$ & $64(26)$ \\
\hline $\mathrm{DO}_{121-150}$ & 37 & $39(2)$ & $33(-4)$ & $48(11)$ & $38(1)$ & $42(5)$ & $36(-1)$ & $39(2)$ \\
\hline $\mathrm{DO}_{211-240}$ & 25 & $22(-3)$ & $24(-1)$ & $26(1)$ & $19(-6)$ & $18(-7)$ & $22(-3)$ & $24(-1)$ \\
\hline $\mathrm{DO}_{>240}$ & 72 & $55(-17)$ & $53(-19)$ & $70(-2)$ & $52(-20)$ & $50(-22)$ & $63(-9)$ & $60(-12)$ \\
\hline
\end{tabular}

${ }^{1}$ Change in number of cows compared with model $\mathrm{G}$ is in parentheses.

${ }^{2} \mathrm{DO}_{\mathrm{NP}}=$ nonpregnant cows; other classes include DO from $\leq 60$ to $>240 \mathrm{~d}$.

${ }^{3} \mathrm{G}=$ general model; $\mathrm{DO}=$ days open model; $\mathrm{MP}=$ month of pregnancy model; $\mathrm{DP}=$ days pregnant model; $\mathrm{SP} \times \mathrm{SL}=$ stage of pregnancy $\times$ stage of lactation model; $\mathrm{DP} \times \mathrm{DO}=$ days pregnant $\times$ days open model; $\mathrm{MP} \times \mathrm{DO}=$ month of pregnancy $\times$ days open; SP $=$ stage of pregnancy model.

\section{ACKNOWLEDGMENTS}

This work was made possible by the facilities of the Shared Hierarchical Academic Research Computing Network (SHARCNET: http://www.sharcnet.ca). Funding was provided by DairyGen Council of Canadian Dairy Network and NSERC of Canada. Appreciation is extended to Ignacy Misztal (University of Georgia, Athens) for providing the BLUPF90iod program. Two anonymous reviewers are thanked for their helpful comments and suggestions.

\section{REFERENCES}

Abdallah, J. M., and B. T. McDaniel. 2000. Genetic parameters and trends of milk, fat, days open, and body weight after calving in North Carolina experimental herds. J. Dairy Sci. 83:1364-1370.
Akers, R. M. 2006. Major advances associated with hormone and growth factor regulation of mammary growth and lactation in dairy cows. J. Dairy Sci. 89:1222-1234.

Bell, A. W., R. Slepetis, and R. A. Ehrhardt. 1995. Growth and accretion of energy and protein in the gravid uterus during late pregnancy in Holstein cows. J. Dairy Sci. 78:1954-1961.

Bohmanova, J., F. Miglior, J. Jamrozik, I. Misztal, and P. G. Sullivan. 2008. Comparison of random regression models with Legendre polynomials and linear splines for production traits and somatic cell score of Canadian Holstein. J. Dairy Sci. 91:3627-3638.

Bormann, J., G. R. Wiggans, T. Druet, and N. Gengler. 2002 Estimating effects of permanent environment, lactation stage, age, and pregnancy on test-day yield. J. Dairy Sci. 85:263-284.

Brotherstone, S., R. Thompson, and I. M. S. White. 2004. Effects of pregnancy on daily milk yield of Holstein-Friesian dairy cattle. Livest. Prod. Sci. 87:265-269.

Coulon, J. B., L. Pérochon, and F. Lescourret. 1995. Modelling the effect of the stage of pregnancy on dairy cows' milk yield. Anim. Sci. 60:401-408.

Druet, T., F. Jaffrezic, D. Boichard, and V. Ducrocq. 2003. Modeling lactation curves and estimation of genetic parameters for first 
lactation test-day records of French Holstein cows. J. Dairy Sci. $86: 2480-2490$

Haile-Mariam, M., P. J. Bowman, and M. E. Goddard. 2003. Genetic and environmental relationship among calving interval, survival, persistency of milk yield and somatic cell count in dairy cattle. Livest. Prod. Sci. 80:189-200.

Interbull. 2008. Description of National Genetic Evaluation Systems for dairy cattle traits as applied in different Interbull member countries. http://www-interbull.slu.se/national_ges_info2/ framesida-ges.htm Accessed Aug. 31, 2008.

Leclerc, H., D. Duclos, A. Barbat, T. Druet, and V. Ducrocq. 2008. Environmental effects on lactation curves included in a test-day model genetic evaluation. Animal 2:344-353.

Lee, J. K., P. M. VanRaden, H. D. Norman, G. R. Wiggans, and T. R. Meinert. 1997. Relationship of yield during early lactation and days open during current lactation with 305-day yield. J. Dairy Sci. $80: 771-776$

Makuza, S. M., and B. T. McDaniel. 1996. Effects of days dry, previous days open, and current days open on milk yields of cows in Zimbabwe and North Carolina. J. Dairy Sci. 79:702-709.

Olori, V. E., S. Brotherstone, W. G. Hill, and B. J. McGuirk. 1997. Effect of gestation stage on milk yield and composition in Holstein Friesian dairy cattle. Livest. Prod. Sci. 52:167-176.
Roche, J. R. 2003. Effect of pregnancy on milk production and bodyweight from identical twin study. J. Dairy Sci. 86:777-783.

Sadek, M. H., and A. E. Freeman. 1992. Adjustment factors for previous and present days open considering all lactations. J. Dairy Sci. 75:279-287.

Schneider, F., J. A. Shelford, R. G. Peterson, and L. J. Fisher. 1981. Effects of early and late breeding of dairy cows on reproduction and production in current and subsequent lactation. J. Dairy Sci. 64:1996-2002.

Sharma, A. K., C. J. Wilcox, F. G. Martin, and W. W. Thatcher. 1990. Effects of stage of lactation and pregnancy and their interactions on milk yield and constituents. J. Dairy Sci. 73:1586-1592.

Tsuruta, S., I. Misztal, and I. Stranden. 2001. Use of the preconditioned conjugate gradient algorithm as a generic solver for mixed-model equations in animal breeding applications. J. Anim. Sci. 79:11661172 .

Varona, L., C. Moreno, L. A. G. Cortés, G. Yagüe, and J. Altarriba. 1999. Two-step versus joint analysis of Von Bertalanffy function. J. Anim. Breed. Genet. 116:331-338. 